\title{
絶縁性試料の光電子顕微鏡（PEEM）観測
}

\author{
大河内 拓 雄 \\ (公財) 高輝度光科学研究センター 函 679-5198 兵庫県佐用郡佐用町光都 1 丁目 1-1 \\ （2013 年 7 月 31 日受付；2013 年 8 月 6 日掲載決定)
}

\section{Photoemission Electron Microscopy (PEEM) on Insulating Samples}

Takuo Онкосні

Japan Synchrotron Radiation Research Institute, 1-1-1 Koto, Sayo, Hyogo 679-5198

(Received July 31, 2013 ; Accepted August 6, 2013)

\begin{abstract}
The observation method of photoemission electron microscopy (PEEM) on insulating samples has been established by introducing simple Au pattern evaporation equipment. Surface conductivity is induced locally on an insulating surface by continuous radiation of soft X-rays, and Au films close to the area of interest allow the accumulated charges to be released to a ground. Using this technique, all users' experiments on poorly conducting samples have been performed successfully at the PEEM experimental station in SPring-8.
\end{abstract}

KEYWORDS : PEEM, insulator, pattern evaporation, ferrite

\section{1.は じめに}

物質の電子状態や磁気状態をマイクロ〜ナノの空間ス ケールで観測する顕微分光法には多くの手法が存在す る。中でも，放射光を用いた光電子顕微鏡（photoemission electron microscopy, PEEM) は, X 線吸収分光 ( $\mathrm{x}$ ray absorption spectroscopy, XAS）やX 線磁気円二色性分 光 (x-ray magnetic circular dichroism, XMCD) として得ら れる情報をサブミクロンスケールで分解できる。PEEM は, 高い空間分解能をもちながら実験試料の適用範囲が 広く, 近年, 様々な研究分野からの新規実験提案がなさ れている。

本稿では, SPring-8 の軟 X 線ビームライン BL17SU に設置されたエネルギー分析型の低エネルギー電子/光 電子顕微鏡装置 (spectroscopic low-energy electron microscope, SPELEEM）における, $\mathrm{Au}$ パターン蒸着法を用い た絶縁性試料の PEEM 研究の展開例を紹介する ${ }^{1)} 。$

\section{PEEM での絶縁性試料の測定}

\subsection{PEEM の特色と利用研究のニーズ}

PEEM は, 試料に光を照射することで光電効果により 放出される電子（主に二次電子）を拡大投影する顕微鏡 である。放出電子強度は入射した光のエネルギーに対す る試料の吸収係数に比例するため, 試料中の注目元素の 吸収端の近傍で $X$ 線エネルギーを掃引しながら像を連 続的に取得することでXAS スペクトルを空間分解して 得ることができる。また，磁性を持った物質については 左右円偏光 $X$ 線を用いて画像を取得すれば，その差分 コントラストから磁区像（XMCD-PEEM 像）が得られ る。例として, Fig. 1 に垂直磁化フェリ磁性体である $\mathrm{GdFeCo}$ 薄膜の, Gd M 4,5 吸収端における PEEM 像（左 右円偏光入射時の像と差分 (XMCD) 像) と, エリア選 択 XAS/XMCD スペクトルを示す ${ }^{2)}$ 。

数多く存在する顕微分光/イメージング手法の中で, PEEM の大きな長所は先に述べた分光特性と元素選択性 であろう。加えて, 視野内の画像情報を一度に取得する 「投影型」の顕微鏡装置であることも大きな特色である。 ナノ〜マイクロサイズのプローブを用いた走査型顕微鏡 では，注目する微小領域の定量的な分光測定に適してい 
(a)

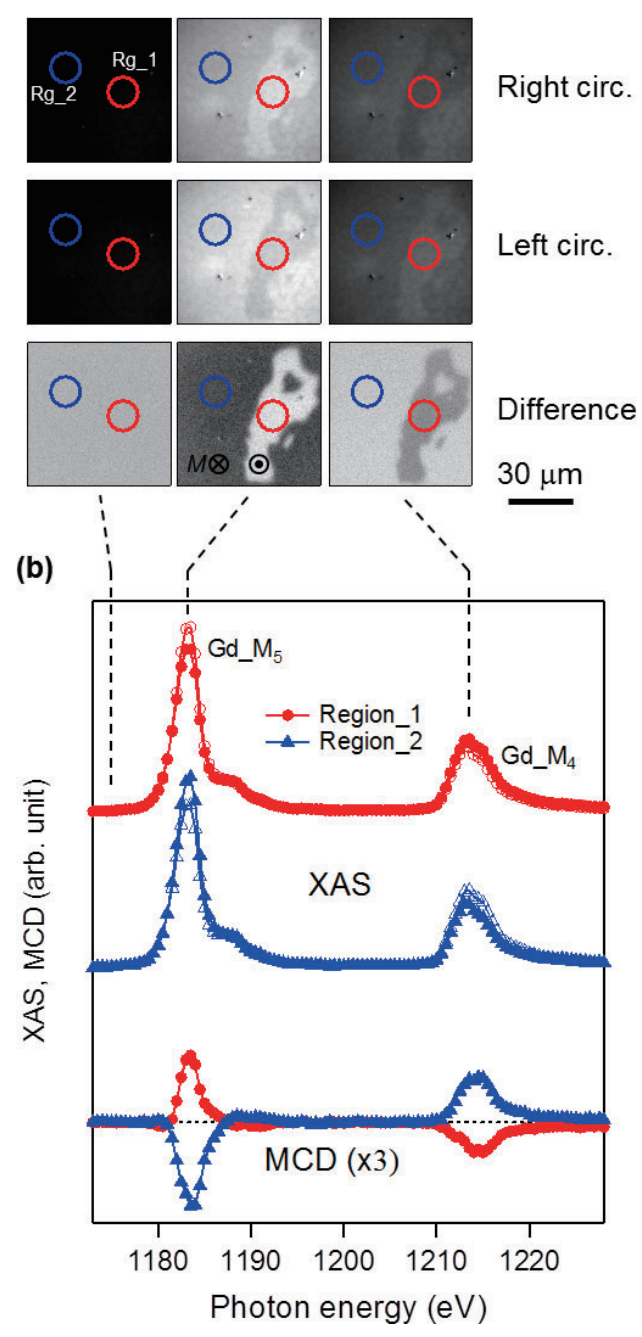

Fig. 1. (color online). (a) PEEM images of a perpendicularly polarized GdFeCo ferrimagnetic film taken around $\mathrm{Gd} \mathrm{M}_{4,5}$ absorption edge. The images are acquired using right- and leftcircularly polarized x-rays and their difference contrast images are also shown. The corresponding photon energies are indicated in the graph shown below. (b) XAS and XMCD spectra plotted at two regions indicated in the images shown above.

るが, 投影型顕微鏡では, 磁区マッピングや元素分布, 電子状態や磁気状態の位置依存性，時間・温度等による コントラスト変化のリアルタイム観察など，画像ベース の解析により適している。また，一般には意外に認識さ れていないが，空間分解能と沉用性のバランスが良い点 も放射光 PEEM の特筆すべき点である。20～30 nm とい う空間分解能は，原子レベルの分解能を持つ走査型トン ネル顕微鏡（scanning tunneling microscope, STM）などと 比べると若干の見劣りはするものの，単結晶など完全性 の高い試料を要求されず，また，透過型 X 線顕微鏡
（Transmission x-ray microscope, TXM）のように基板を含 めた試料の薄膜化の必要がない。つまり, 試料形状に対 する制約が少ないため, 利用側のアイデア次第で非常に 幅広い研究が展開できる。近年では SPring-8 の PEEM 装置に打いても, 酸化物, 半導体, ポリマー, 岩石や地 球外物質队など，これまで我々が対象としていなかった 新規分野からの顕微分光研究の提案が多くなされてい る。

一方, PEEM の短所のひとつとして, 放出電子を計測 する手法であるため, 導電性の低い試料では带電により 適切な結像ができない点がある。上述した物質系の多く はこの絶縁性物質に該当する。逆に，この点を克服でき れば, 新規研究領域への顕微分光測定の水平展開が可能 になる。このような背景を動機として，我々はPEEM で絶縁性試料を観察する手法を確立した。

\section{$2.2 \mathrm{Au}$ パターン蒸着法}

絶縁性試料に扔ける带電の解消法として, 光電子分光 (photoemission electron spectroscopy, PES) に代表される 電子計測法では, 試料表面での損失電荷を補うため低エ ネルギーの電子を照射する手法がよく用いられてい る4)。しかし，電子照射量に任意性があると表面電位が 厳密に補償されないため適切な結像ができず, 特にイメ ージング手法には適さない。一方, PEEM で多く用いら れる手法として，Pdや Pb な゙濡れ性の良い金属を，二 次電子の検出深さよりも若干浅い, 数 $\mathrm{nm}$ の厚さで試料 全体に渡って蒸着する方法もある5)。これは物質系によ っては有効であるが，観測領域も金属薄膜で埋もれてし まうため, 微小なシグナル検出が必要な物質系では注目 元素の情報を十分に得られない。また, 岩石の研磨面な ど凹凸の大きな試料では, 表面電荷を逃がすためかなり の厚さの金属膜蒸着が必要で, 目的物の観測ができなく なる。

ここで紹介する手法では，PEEM 実験槽に試料を導入 する前に, あらかじめ, 実際に観察を行う幅数 $10 \mu \mathrm{m}$ の領域を除いた試料基板全体に十分な厚さ $(>100 \mathrm{~nm})$ の $\mathrm{Au}$ 膜を蒸着することで带電効果を低減することを狙 いとしている。このためのパターン蒸着機構を Fig. 2 に 示す ${ }^{1)}$ 。高さ・幅・奥行ともに $30 \mathrm{~cm}$ 程度の小型チャン バーとターボ分子ポンプ, 抵抗加熱による $\mathrm{Au}$ 蒸着源と 試料ホルダからなる非常にシンプルな装置である。観察 領域をマスクするために，所望の露出幅に合わせた径の タングステン線を張った $\mathrm{Cu}$ フレームを使用している。 市販のメタルマスクを利用するのに比へ，観察領域以外 の領域をほぼすべて金属膜で覆うのに適している。一連 のパターン蒸着は, 試料の装着から真空引き, 蒸着, 大 気解放までを含め 1 時間程度で行うことができる。 
(a)

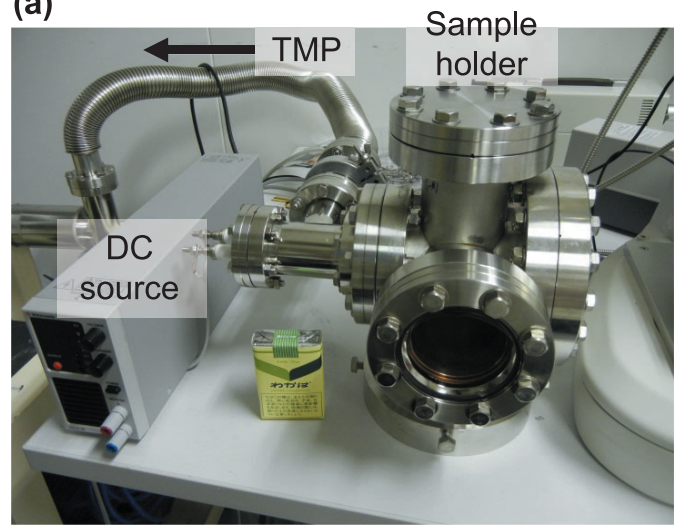

(b)

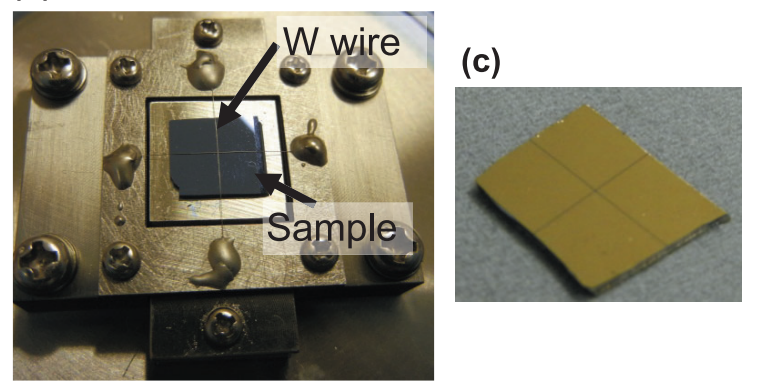

Fig. 2. (color online). Photographs of (a) Au pattern evaporator, (b) Si substrate fixed by tungsten wire and (c) Si substrate with Au patterned film. ${ }^{1)}$ (This figure is reprinted from reference No. 1 under IUCr's copyright permission.)

\section{3 PEEM 実験}

PEEM 実験は, SPring-8 の BL17SU 軟 X 線ビームラ インで行った6,7)。ここでは可変偏光アンジュレーター により，300-1800 eV の直線/円偏光 X 線が得られる ${ }^{8)}$ 。 $\mathrm{X}$ 線は装置の直前のミラーで $30 \mu \mathrm{m}$ 程度に集光されて いる。本ビームラインに設置された SPELEEM 装置 （ELMITEC 社 LEEM III）は世界でも最高水準の空間分 解能を持ち, 軟 X 線領域の PEEM 観測において $22 \mathrm{~nm}$ の分解能を記録している, 10)。PEEM 観測だけでなく, 低エネルギー電子線を用いたイメージング (low-energy electron mimcroscopy, LEEM）や多彩なレンズモードを 利用した局所領域での PES, 電子線回折 (low-energy electron diffraction, LEED）なども可能であるが, 本稿で はPEEMによる結果を紹介する。

\section{3. 結 果 と考察}

\section{3. $1 \mathrm{NiZn}$ フェライトの結晶粒と磁区観察}

最初に, NiZn フェライトの焼結体 ${ }^{11)}$ の PEEM 観測の 結果を紹介する。フェライトは, 一般に電気抵抗が 1 $\mathrm{k} \Omega \cdot \mathrm{cm}$ のオーダーの導電性の低い磁性セラミックであ る。Fig.3（a）に, $30 \mu \mathrm{m}$ 幅の観測領域以外を $100 \mathrm{~nm}$
程度の $\mathrm{Au}$ 膜で覆った NiZn フェライトの PEEM 像を示 す ${ }^{1)}$ 。 $\mathrm{Fe}$ の $\mathrm{L}_{2,3}$ 吸収端周辺である $730 \rightarrow 700 \mathrm{eV}$ で放射 光エネルギーを掃引して得た像であるが，ここでは主に 軟 X 線の照射時間の依存性に注目されたい。このエネ ルギー領域ではフォトン数は凡そ〜 $7 \times 10^{12}$ photons $\cdot \mathrm{s}^{-1}$ で, 約 $\phi 30 \mu \mathrm{m}$ のスポットに照射されている。観察初期 (0 min.) は露出したフェライト部は帯電して光電子が ほとんど放出されず画像コントラストが得られていない が, 時間の経過とともに像は明るくなり, 放射光照射か ら 30 分を経過する頃には $\mathrm{Au}$ とフェライトの境界が明 確に識別でき, 適正に結像できていることがわかる。

光照射による帯電解消のメカニズムを Fig. 3（b）に 示す ${ }^{1)}$ 。高輝度の放射光照射により, 真空槽内（本装置 では, $5 \times 10^{-9}$ Torr 程度）の単離した C や O などの残 留気体原子が表面に沈着し, 原子層レベルの超薄導電膜 を形成して局所表面導電性が得られると考えられる ${ }^{12)} 。$ パターン蒸着を施していない試料の場合は, たとえ局所 導電性ができても周囲が絶縁性であるため帯電荷を接地 電位（試料ホルダ）に逃がすことができないが, 露出部 の幅が放射光のサイズよりも小さければ $\mathrm{Au}$ パッドが電 荷の逃げ道となるため, 完全に補償された表面電位での 像観察が可能となる。

このようにして導電性ができた領域を拡大して詳細な 像観察を行った結果を Fig. 3 (c) に示す ${ }^{1)}$ 。左右円偏光 $\mathrm{X}$ 線で取得した像を足し合わせて磁気情報をキャンセル アウトしたXAS-PEEM 像では 5〜 $10 \mu \mathrm{m}$ サイズの結晶 粒界がきわめて明瞭に観察できている。左右円偏光の差 分像であるXMCD-PEEM 像 (磁区像) を見ると, さら に細かいサイズの多磁区が形成されており, 磁壁が結晶 粒界と無関係に走っている様子も一目瞭然である。 PEEM と同じ投影型の偏光顕微鏡である Kerr 顕微鏡で は, 結晶粒と磁区の情報の分離が困難であったが, 本実 験により初めてそれぞれの形状を独立して得ることがで きた。

\section{2 サファイア基板の PEEM と局所分光}

前節の NiZn とまったく同様の手法を適用することに より, 絶縁性がきわめて高いサファイア $\left(\sim 10^{14} \Omega \cdot \mathrm{cm}\right)$ などでも PEEM 観測や局所XAS 測定が可能である。 Fig. 3 (d) に, Al の K 吸収端 $(1567 \mathrm{eV})$ で取得したサ ファイア基板の PEEM 像を示す ${ }^{1)}$ 。このエネルギー領域 でのフォトン数は凡そ〜 $2 \times 10^{12}$ photons $\cdot \mathrm{s}^{-1}$ である。幅 $20 \mu \mathrm{m}$ の露出領域を除いて $\mathrm{Au}$ を蒸着したサファイア基 板では, 1 時間程度の照射後に鮮明な像が観察されてい る（Fig. 3 (d) 左)。一方, $\mathrm{Au}$ パターン膜を付与してい ない試料では, 有意な像コントラストはまったく確認で きない（Fig. 3 (d) 右)。Fig. 3（e）にそれぞれの試料 
(a)

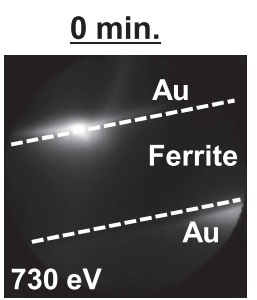

(b)

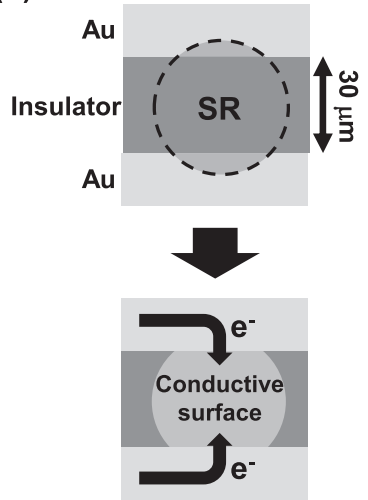

(c)

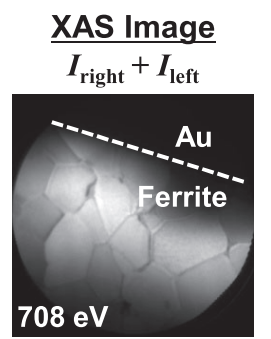

(d)

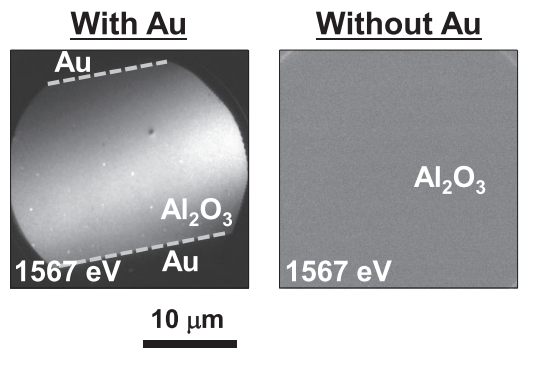

(e)

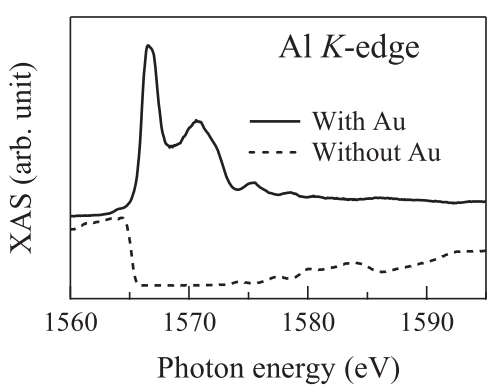

Fig. 3. (a) PEEM images of NiZn ferrite surrounded by Au pads during the course of radiation of soft $x$-rays around the $\mathrm{Fe}_{3}$-edge (700-730 eV) for 0-30 min. (b) Schematics of an insulating sample surrounded by thick Au pads and its process of obtaining electric conductivity by high density photon irradiation. (c) XAS and XMCD images of NiZn ferrite at the absorption peak of the $\mathrm{Fe}_{3}$-edge $(708 \mathrm{eV})$ after irradiation of synchrotron radiation for $\sim 30$ min. (d) PEEM images at the Al K-edge $(1567 \mathrm{eV})$ and (e) XAS spectra around the Al K-edge of a sapphire substrate with (solid line) and without (dotted line) Au pads. ${ }^{1)}$ (This figure is reprinted from reference No. 1 under IUCr's copyright permission.)

について視野の中心でプロットしたXAS スペクトルを 示している。 $\mathrm{Au}$ パッド付き試料ではアルミニウム酸化 物に特徴的な XAS スペクトル ${ }^{13)}$ が鮮明に得られている のに対し, $\mathrm{Au}$ パターンのない試料ではシャープな吸収 ピークが現れるべきエネルギー $(1567 \mathrm{eV})$ でむしろ光 電子強度が減少している。これは, X 線吸収量の増加に よって試料の帯電が促進されたためである。

\section{3 電池電極材料 $\mathrm{Li}_{0.9} \mathrm{CoO}_{2}$ 薄膜}

前節で示したように, 観察領域近傍の $\mathrm{Au}$ 薄膜は光電 子放出によって生成された正電荷の逃げ道として機能し ている。ここでは, この $\mathrm{Au}$ 膜が放出光電子の軌道を安 定化させ, 分解能良く結像するためにも重要な働きをす ることを示す。Fig. 4 に, サファイア基板上に成長させ た $\mathrm{Li}_{0.9} \mathrm{CoO}_{2}$ 薄膜（厚さ〜 $100 \mathrm{~nm}$ ）の, $\mathrm{Au}$ パターン蒸着 を施した場合と施していない場合の PEEM 像の比較を 示している ${ }^{1)}$ 。観測は酸素の $\mathrm{K}$ 吸収端周辺のエネルギー (530-570 eV) で行った。 $\mathrm{Li}_{0.9} \mathrm{CoO}_{2}$ は電池電極材料とし て知られており, バルクでは導電体であるが, 薄膜の場 合は表面で炭酸リチウムを生成しており比抵抗が数 100 $\Omega \cdot \mathrm{cm}$ 程度と導電性が低くなっている。こういった試料
では $\mathrm{Au}$ パターン蒸着を行っていない場合でも（Fig. 4 (a)）結像はある程度可能であるが，像は若干不明暸で， 矢印で示した defect の位置が時間と共に不規則に移動し ていることがわかる。これは試料とレンズとの相対位置 の物理的ドリフトによるものではなく, 正電荷が速やか に逃げることができないため, 表面電位の時間変化によ る光電子軌道の変化に起因するものである。含有元素の 吸収端近傍でのエネルギー掃引測定では, 電子放出量 (吸収係数) の変化が表面電位の変化を生むので,この 傾向は特に顕著になる。一方, 幅 $30 \mu \mathrm{m}$ の露出領域の ある $\mathrm{Au}$ パターン蒸着試料では (Fig. 4 (b)), 未蒸着の 試料の場合と比べて画像コントラストが細部にわたって クリアに確認できる（この観測では, 前述の NiZn フェ ライトのように, 放射光照射による局所導電性を持たせ る手順は踏んでいない)。Fig. 4 (c) に, 久陥の位置か ら見積もったドリフト量をプロットしているが, $\mathrm{Au}$ パ ッドがない場合は数 $\mu \mathrm{m}$ の像のシフトがあるのに対し, 周囲に $\mathrm{Au}$ を蒸着したものは数 $10 \mathrm{~nm}$ 程度で, これは試 料マニピュレーターの物理的なドリフトで説明できる範 囲である。 
(a)
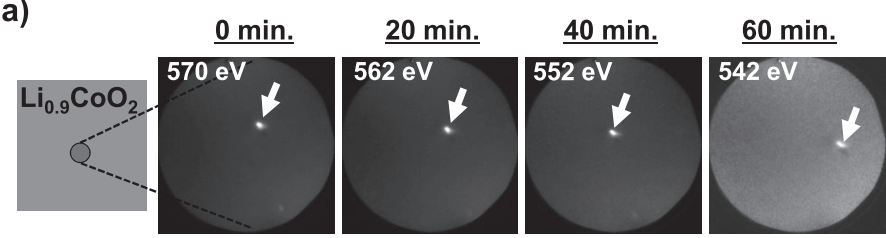

$2 \mu \mathrm{m}$

(b)

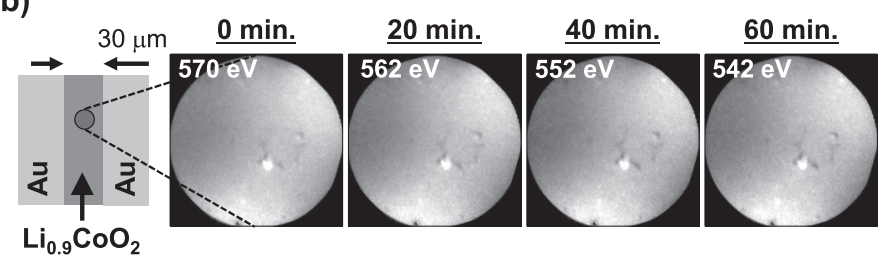

(c)

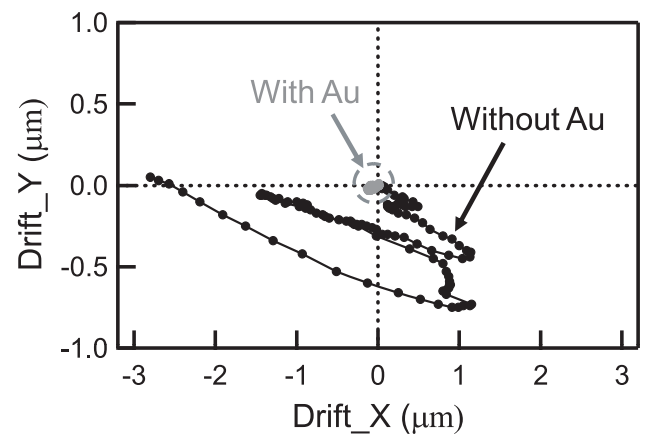

Fig. 4. (a) PEEM images of $\mathrm{Li}_{0.9} \mathrm{CoO}_{2}$ film during the course of an XAS scan around the $\mathrm{O}$ K-edge $(530-570 \mathrm{eV})$ for $\sim 60$ min. (b) Similar images to those in (a) but of $\mathrm{Li}_{0.9} \mathrm{CoO}_{2}$ film covered by Au pads. (c) Plots of displacements of PEEM images on $\mathrm{Li}_{0.9} \mathrm{CoO}_{2}$ samples with and without $\mathrm{Au}$ pads during the course of PEEM observations around the $\mathrm{O} \mathrm{K}$-edge for $\sim 80$ min. ${ }^{1)}$ (This figure is reprinted from reference No. 1 under IUCr's copyright permission.)

一般的な電子収量実験では, 数 $100 \Omega \cdot \mathrm{cm}$ 程度の導電 性でもある程度の分光測定が可能であるが，適正に「結 像」を行うためには試料基板全体の巨視的な表面電場を 安定させる必要がある。そのために, 観察領域を除くす べての領域に導電性金属を蒸着することの重要性が, こ の結果からも明らかである。

\section{4. まとめと今後の課題}

本稿で紹介した $\mathrm{Au}$ パターン蒸着の方法は, バルクや 連続薄膜だけでなく, 樹脂基板に埋め込まれた数 $10 \mu \mathrm{m}$ サイズの希少な粒子状試料（たとえば，地球外物質な ど）への適用例もある。蒸着時に観察領域をマスクする タングステン線の位置は, 光学顕微鏡でモニタしながら $10 \mu \mathrm{m}$ 程度の精度で決めることができる。また, タング ステン線によりできる十字状の絶縁体領域のパターン は, 広い基板上の小さな目的物を PEEM の視野上で探 し出すのにも役立っている。

こういった試料の测定を含め, 本ビームラインの LEEM/PEEM 装置における絶縁性試料のユーザー実験 課題は, 最も多い時期（2010下半期〜2012 上半期）で は30 課題中 13 課題と $40 \%$ を超えた。これらのすべて の課題において, 本手法を適用することで帯電問題を解 消して適正な観測を行うことができた。

ただし，この手法において局所表面伝導性を生んでい るのは真空中の残留気体分子という不純物の薄膜であ る。これは通常の導電性試料の測定においても発生して いるもので, 絶縁性試料でも, 無機物質では試料そのも のに深刻なダメージを与える例は少ないが，たとえばポ
リマーなどの有機物質では明らかな照射ダメージが確認 されている。その場合は，パターン膜を付与した後に観 察領域にもごく薄い金属保護膜を付加する二段蒸着など の工夫が必要になる ${ }^{14)}$ 。また，発生する表面不純物につ いてその素性を明らかにする実験・研究も，今後の放射 線照射効果の有効利用において重要な課題である。

\section{謝 辞}

本開発を遂行するにあたり，本実験ステーションおよ び研究グループの統括, 並びに多くの助言を下さいまし た JASRI の渡辺義夫主席研究員 (現：JST-ERATO/慶応 大学), 室隆桂之主幹研究員, 本ビームラインを統括さ れている理化学研究所の大浦正樹ユニットリーダーに感 謝致します。本開発は小嗣真人研究員 (JASRI) との共 同で実施されました。試料提供および PEEM 実験につ いて, 太陽誘電株式会社の河野健二博士, 東京大学放射 光連携研究機構の尾嶋正治教授, 堀場弘司准教授, 東北 大学 WPI-AIMR の一杉太郎准教授, 白木将講師, 九州 大学理学研究院の北島富美雄助教, 京都大学化学研究所 の小野輝男教授, 山田啓介博士 (現 : 電気通信大学) に 御協力頂きました。PEEM 実験の結果に関して, JASRI の木下豊彦主席研究員より有益な助言を頂きました。一 連の実験は, SPring-8 の BL17SU ビームラインにおいて 課題番号 20090094 (理研), 2010B1746, 2010B1767, 2011B1289，2011B1898（JASRI）で実施されました。 この場を借りて感謝申し上げます。 


\section{文献}

1) T. Ohkochi, M. Kotsugi, K. Yamada, K. Kawano, K. Horiba, F. Kitajima, M. Oura, S. Shiraki, T. Hitosugi, M. Oshima, T. Ono, T. Kinoshita, T. Muro and Y. Watanabe : J. Synchrotron Rad. 20, 620 (2013).

2) T. Ohkochi, H. Fujiwara, M. Kotsugi, A. Tsukamoto, K. Arai, S. Isogami, A. Sekiyama, J. Yamaguchi, K. Fukushima, R. Adam, C.M. Schneider, T. Nakamura, K. Kodama, M. Tsunoda, T. Kinoshita and S. Suga : Jpn, J. Appl. Phys. 51, 073001 (2012).

3) M. Kotsugi, C. Mitsumata, H. Maruyama, T. Wakita, T. Taniuchi, K. Ono, M. Suzuki, N. Kawamura, N. Ishimatsu, M. Oshima, Y. Watanabe and M. Taniguchi : Appl. Phys. Express 3, 013001 (2010).

4) M.A. Kelly : J. Electron Spectrosc. Relat. Phenom. 176, 5 (2010).

5) B. Gilbert, G. Margaritondo, S. Douglas, K.H. Nealson, R.F. Egerton, G.F. Rempfer and G. De Stasio : J. Electron Spectrosc. Relat. Phenom. 114, 1005 (2001).

6) H. Ohashi, Y. Senba, H. Kishimoto, T. Miura, E. Ishiguro, T. Takeuchi, M. Oura, K. Shirasawa, T. Tanaka, M. Takeuchi, K. Takeshita, S. Goto, S. Takahashi, H. Aoyagi, M. Sano, Y. Furukawa, T. Ohata, T. Matsushita, Y. Ishizawa, S. Taniguchi, Y. Asano, Y. Harada, T.
Tokushima, K. Horiba, H. Kitamura, T. Ishikawa and S. Shin : AIP Conf. Proc. 879, 523 (2007).

7) Y. Senba, H. Ohashi, H. Kishimoto, T. Miura, S. Goto, S. Shin, T. Shintake and T. Ishikawa : AIP Conf. Proc. 879, 718 (2007).

8) M. Oura, T. Nakamura, T. Takeuchi, Y. Senba, H. Ohashi, K. Shirasawa, T. Tanaka, M. Takeuchi, Y. Furukawa, T. Hirono, T. Ohata, H. Kitamura and S. Shin : J. Synchrotron Rad. 14, 483 (2007).

9) E. Bauer : Ultramicroscopy 119, 18 (2012).

10) F. -Z. Guo, T. Muro, T. Matsushita, T. Wakita, H. Ohashi, Y. Senba, T. Kinoshita, K. Kobayashi, Y. Saitoh, T. Koshikawa, T. Yasue, M. Oura, T. Takeuchi and S. Shin : Rev. Sci. Instrum. 78, 066107 (2007).

11) K. Kawano, M. Hachiya, Y. Iijima, N. Sato and Y. Mizuno : J. Magn. Magn. Mater. 321, 2488 (2009).

12) B. Gilbert, R. Andres, P. Perfetti, G. Margaritondo, G. Rempfer and G. De Stasio : Ultramicroscopy 83, 129 (2000).

13) T. Kinoshita, Y. Takata, T. Matsukawa, H. Aritani, S. Matsuo, T. Yamamoto, M. Takahashi, H. Yoshida, T. Yoshida, Y. Ufuktepe, K.G. Nath, S. Kimura and Y. Kitajima : J. Synchrotron Rad. 5, 726 (1998).

14) G. De Stasio, B.H. Frazer, B. Gilbert, K.L. Richter and J.W. Valley : Ultramicroscopy 98, 57 (2003). 